Economic Education Journal

Volume.1, Issu.1 January 2019, 9-14

http://ejurnal.ung.ac.id/index.php/jej

\title{
Pengaruh Penggunaan Telepon Seluler Terhadap Hasil Balajar Mahasiswa pada Program Studi S1 Pendidikan Ekonomi Angakatan 2015 Fakultas Ekonomi Universitas Negeri Gorontalo
}

\author{
Maryam Ilato'. Muhammad Amir Arham², Boby R. Payu ${ }^{3}$ \\ Universitas Negeri Gorontalo, Gorontalo, Indonesia \\ maryamilato@gmail.com
}

\begin{abstract}
This research aims at investigating in what extent the influence of mobile phone utilization towords students' learning achievement in bachelor study Program of Economics, Batch of 2015, Faculty of Economics, State University of Gorontalo. It applies quantitative method. Techniques of date collection are observation, questionnaire, and documentation and technique of date analysis is simple linear regression. Samples are 42 students. Finding reveals that mobile phone positively influences learning achievement students of Dapartement of Economics, State of University of Gorontalo. The higher the frequency of students in using mobile phone in learning process leads to tower their learning achievement.
\end{abstract}

\section{ARTICLE HISTORY}

Received 25 September 2018

Accepted 10 Desember 2018

\section{KEYWORDS}

Mobile Phone Utilization;

Learning achivement

\section{Pendahuluan}

Hasil belajar merupakan hasil dari suatu interaksi tindak mengajar, dan hasil belajar merupakan tujuan akhir dilaksanakannya kegiatan belajar. Khususnya diperguruan tinggi, hasil belajar merupakan tujuan akhir dilaksanakannya mata kuliah di kampus. Hasil belajar dapat ditingkatkan melalui usaha sadar yang dilakukan secara sistematis mengarah kepada perubahan yang positif yang kemudian disebut dengan proses belajar. Akhir dari proses belajar adalah perolehan suatu hasil belajar mahasiswa.
Dari sisi dosen hasil belajar mahasiswa di kelas terkumpul dalam himpunan hasil belajar, sedangkan dari sisi mahasiswa, hasil belajar merupakan berakhirnya panggal dan puncak proses belajar. Hal ini juga ungkapkan oleh (Nashar, 2004: 77), bahwa hasil belajar dapat dikatakan sebagai perubahan perilaku yang diperoleh setelah melalui kegiatan belajar. Jadi hasil belajar merupakan pencapaian tujuan belajar dan hasil belajar sebagai produk dari proses belajar, maka di dapat hasil belajar.

Jambura : Economic Education Journal,Volume 1, Issue 1 January 2019. 
Hasil belajar sangat diperlukan di perguruan tinggi karena dengan adanya hasil belajar dosen dapat mengetahui apakah pembelajaran yang telah diajarkan sudah tersampaikan dengan baik, atau sesuai dengan tujuan pembelajaran, ataukah belum sama sekali. Dan jika hal-hal tersebut terjadi dalam menjalankan pembelajaran maka mahasiswa akan melakukan evaluasi terhadap pencapaian hasil belajarnya. Sehingga pada saat melakukan pembelajaran kembali mahasiswa sudah menjadi lebih baik. Karena mahasiswa mencari tambahan lain melalui penggunaan teknologi misalnya penggunaan telepon seluler.

Penggunaan telepon seluler pun semakin luas, tidak hanya di kalangan atas yang bisa menggunakannya, kini seluruh lapisan masyarakat bisa mengaksesnya. Telepon seluler merupakan perangkat telekomunikasi elektronik yang mempunyai kemampuan dasar yang sama dengan telepon konvesional saluran tetap, namun dapat di bawah ke mana-mana dan tidak perlu disambungkan dengan jaringan telepon menggunakan kabel. Dengan penggunaan telepon seluler harusnya mahasiswa mampu mencari informasi yang seluas-luasnya dan tidak terbatas. yang penting bisa terhubung dengan jaringan internet.

Penggunaan telepon seluler pun mulai beragam, tidak hanya untuk menelpon dan mengirim pesan saja tetapi juga digunakan untuk akses internet, mengabadikan berbagai kejadian dengan kamera, dan fitur-fitur canggih lainnya. Fitur-fitur canggih inilah yang membuat mahasiswa ketergantungan dengan telepon seluler mereka. Ketergantungan akan telepon seluler akan membuat mahasiswa menghabiskan waktu yang lama dengan telepon seluler mereka dibandingkan kegiatan lainnya. Hal ini juga akan mengurangi waktu belajar mahasiswa. Ketertarikan akan telepon seluler lebih besar dari pada belajar. Mereka lebih tertarik untuk memainkan telepon seluler dibandingkan membaca buku untuk belajar.

Hasil observasi awal yang dilakukan oleh peneliti di Fakultas Ekonomi khususnya di Program Studi Pendidikan Ekonomi Angkatan 2015 yaitu kecenderungan mahasiswa menggunakan telepon seluler pada saat belajar. Hal ini dapat dilihat dari: bermain-main handphone (sms, bermain game, chatting di sosial media) ketika dosen menjelaskan, mahasiswa cenderung menggunakan telepon seluler pada saat dosen menjelaskan, ketika mendapat tugas dari dosen masih terdapat mahasiswa yang mengerjakan tugas secara mendadak dan itupun mengandalkan pekerjaan teman serta mengandalkan tugas melalui internet. Dan semua hal tersebut berdampak pada hasil belajar mahasiswa.

Berdasarkan latar belakang di atas, maka peneliti tertarik untuk mengkaji sejauh mana "Pengaruh Penggunaan Telepon Seluler Terhadap Hasil Balajar Mahasiswa pada Program Studi S1 Pendidikan Ekonomi Angakatan 2015 Fakultas Ekonomi Universitas Negeri Gorontalo."

\section{Kajian Teori}

\section{Pengertian Hasil Belajar}

Hasil belajar adalah merupakan tujuan akhir dilaksanakannya kegiatan pembelajaran di sekolah. Hasil balajar dapat ditingkatkan melalui usaha sadar yang dilakukan secara sistematis mengarah kepada perubahan yang positif yang kemudian disebut dengan proses belajar. Akhir dari proses belajar adalah perolehan suatu hasil belajar 
siswa. Hasil belajar siswa di kelas terkumpul dalam himpunan hasil belajar kelas. Semua hasil belajar tersebut merupakan hasil dari suatu interaksi tindak belajar dan tindak mengajar. Dari sisi guru, tindak mengajar diakhiri dengan proses evaluasi hasil belajar, merupakan berakhirnya penggal dan puncak proses belajar (Dimyati dan Mudjiono, 2009).

\section{Faktor-Faktor Yang Mempengaruhi Hasil Belajar}

Ada beberapa faktor-faktor yang mempengaruhi menurut Dalyono (1997) berhasil tidaknya seseorang dalam belajar disebabkan oleh dua factor yaitu sebagai berikut:

Faktor Internal

Faktor internal adalah seluruh aspek yang terdapat dalam diri individu yang belajar.

\section{Kesehatan}

Kesehatan jasmani dan rohani sangat besar pengaruhnya terhadap kemampuan belajar, seseorang yang tidak selalu sehat, sakit kepala, demam, pilek batuk dan sebagainya dapat mengakibatkan tidak bergairah untuk belajar. Demikian juga halnya jika kesehatan rohani (jiwa) kurang baik.

\section{Intelegensi Dan Bakat}

Kedua aspek kejiwaan ini besar sekali pengaruhnya terhadap kemampuan belajar. Seseorang yang mempunyai intelegensi yang baik (IQ-nya tinggi). Umumnya mudah belajar dan hasilnya pun cenderung baik. Bakat juga besar pengaruhnya dalam menentukan keberhasilan belajar. Jika sesorang mempunyai intelegensi yang tinggi dan bakatnya ada dalam bidang yang dipelajari, maka proses belajar akan lebih mudah dibandingkan orang yang hanya mempunyai intelegensi tinggi saja atau bakat saja.

\section{Minat Dan Motivasi}

Minat dapat timbul karena adanya daya tarik dari luar dan juga datang dari sanubari, timbulnya minat belajar disebabkan beberapa hal, antara lain karena keinginan yang kuat untuk menaikan martabat atau ingin memperoleh pekerjaan yang baik hasrat ingin hidup senang atau bahagia, begitu pula seseorang yang belajar dengan motivasi yang kuat, akan melaksanakan kegiatan belajarnya dengan sungguhsungguh, penuh gairah dan semangat.

Cara Belajar

Cara belajar juga mempengaruhi pencapaian hasil belajarnya, belajar tanpa memperhatikan tekhnik dan faktor pisiologis, psikologis, dan ilmu kesehatan akan memperoleh hasil yang kurang.

1. Faktor Eksternal

\section{Keluarga}

Factor orang tua sangat besar pengaruhnya terhadap keberhasilan anak dalam belajar, misalnya tinggi rendahnya pendidikan, besar kecilnya perhatian dan penghasilan.

Sekolah

Keadaan sekolah tempat belajar cukup berpengaruh tingkat keberhasilan anak. Kualitas guru, metode mengajarnya, kesesuaian kurikulum dengan kemampuan anak, keadaan fasilitas atau perlengkapan disekolah dan sebagainya, semua ini akan mempengaruhi kegiatan belajar.

\section{Pengertian Telepon Seluler}

1. Menurut Wiranto (2004) telepon seluler merupakan salah satu teknologi komunikasi yang bisa dikatakan sebagai media komunikasi interpersonal maupun media komunikasi kelompok dengan dilengkapi

Jambura : Economic Education Journal,Volume 1, Issue 1 January 2019. 
berbagai macam fitur yang canggih yang membuat pengguna tidak akan bosan untuk mengoperasikan telepon seluler miliknya. Hal tersebut menjadikan waktu pelajar yang seharusnya digunakan untuk belajar justru terbuang sia-sia, karena waktu belajar yang kurang maka dapat menurunnya prestasi dan mengganggu aktivitas belajar. Telepon seluler (ponsel) atau handphone (HP) adalah perangkat telekomunikasi elektronik yang mempunyai kemampuan dasar yang sama dengan telepon konvensional saluran tetap, namun dapat dibawa kemana-mana dan tidak perlu disambungkan dengan jaringan telepon menggunakan kabel.

\section{Dampak Penggunaan Telepon Seluler Dampak Positif}

(Uswatun www.eduksi.kompasiana.com, 16 agustus 2017) mengemukakan secara umum dampak positif telepon seluler terbagi atas 5 yaitu: 1). Mempermudah komunikasi (Melakukan komunikasi dengan orang tua). Peran ini memang vital terutama bagi siswa yang relatif jauh rumahnya dari sekolah dan ada kendala transportasi. Untuk itu peranan telepon seluler sangat penting sekali untuk memastikan kapan dan kapan jemputan diperlukan; 2). Mencari informasi IPTEK lewat internet, hal ini dimungkinkan dengan penemuan seri handphone canggih generasi 3G yang memberikan kesempatan penggunanya untuk browsing internet lewat Handphone; 3). Memperluas jaringan persahabatan dengan mengakses jejaring sosial yang bisa kita dapatkan dengan mendownload aplikasi java yang sesuai dengan handphone kita; 4). Mempermudah kegiatan belajar, handphone yang dilengkapi feature seperti Document Viewer dapat membantu pelajar dalam mempelajari materi dalam bentuk ebook atau pdf secara portable dengan mudah; 5). Membantu pelajar untuk berlatih English conversation dengan format Mp3 atau Mp4; 6). Menghilangkan kepenatan pelajar setelah belajar dengan mendengarkan music dengan feature Mp3 player atau radio Fm.

\section{Dampak Negatif}

Menurut (Uswatun www. eduksi. kompasiana. com, 16 agustus 2017 ), dampak penggunaan telepon seluler terhadap pelajar itu sangat membahayakan jika digunakan dengan maksud yang tidak jelas dan dapat merugikan baik diri sendiri maupun orangtua. Guru juga sangat dirugikan oleh telepon seluler. Telepon seluler dapat menghambat pemberian pelajaran kepada para pelajarnya.

\section{Metode Penelitian}

Sehubungan dengan penulisan proposal ini, tempat penelitian ini dilakukan di Fakultas Ekonomi khususnya program studi pendidikan ekonomi angkatan 2015. Penelitian ini dilaksanakan selama 3 bulan yang mencakup semua langkah-langkah penelitian, mulai dari persiapan sampai dengan pelaksanaan penelitian.

\section{Pembahasan}

Hasil belajar dapat ditingkatkan melalui usaha sadar yang dilakukan secara sistematis mengarah kepada perubahan yang positif kemudian disebut dengan proses belajar. Akhir dari proses belajar adalah perolehan suatu hasil belajar mahasiswa. Dari sisi dosen hasil belajar mahasiswa di kelas terkumpul dalam himpunan hasil belajar, sedangkan dari sisi mahasiswa, hasil belajar merupakan berakhirnya panggal dan puncak proses belajar.

Jambura : Economic Education Journal,Volume 1, Issue 1 January 2019. 
Sehingga hasil belajar adalah hasil dari suatu interaksi tindak mengajar yang memberikan arah pada kegiatan belajar, sehingga dapat mencapai hasil yang baik. Jadi hasil belajar bagi mahasiswa sangat penting. Dengan adanya hasil belajar mahasiswa akan lebih termotivasi untuk belajar agar dapat meningkatkan, memperkuat dan mengarahkan proses belajarnya dengan baik, sehingga akan memperoleh keefektifan dalam belajar.

Hasil belajar merupakan hal yang perlu diperhatikan karena kebanyakan mahasiswa mengalami masalah belajar yang berdampak pada rendahnya hasil belajar. upaya yang harus dilakukan untuk mencapai hasil belajar yang baik membutuhkan usaha yang maksimal karena hasil belajar dapat dipengaruhi oleh berbagai faktor dan salah satunya adalah penggunaan telepon seluler pada mahasiswa di Jurusan Pendidikan Ekonomi Angkatan 2015 Fakultas Ekonomi Universitas Negeri Gorontalo.

Dari hasil penelitian diketahui bahwa terdapat pengaruh penggunaan telepon seluler terhadap hasil belajar mahasiswa di Jurusan Pendidikan Ekonomi Angkatan 2015 Fakultas Ekonomi Universitas Negeri Gorontalo yang ditunjukan oleh nilai koefisien regresi $Y=0,657+0,709$ X. Selain itu setelah dilakukan uji hipotesis didapatkan hasil bahwa nilai t nilai t-hitung untuk variabel Telepon Seluler diperoleh sebesar 3,97 sedangkan nilai t-tabel pada tingkat signifikansi 5\% dengan derajat bebas $\mathrm{df}=39$ sebesar 2,023. Jika kedua nilai $t$ ini dibandingkan maka nilai t- hitung masih lebih besar dibandingkan dengan nilai ttabel $(3,97>2,023)$.demikian hipotesis dapat dinyatakan berpengaruh positif dari penggunaan telepon seluler terhadap hasil belajar mahasiswa dapat diterima hipotesisnya.

Dapat pula dilihat dari nilai koefisien determinasi ditemukan bahwa nilainya sebesar 0.440 atau dengan kata lain $44 \%$ variabilitas Hasil Belajar Mahasiswa di Jurusan Pendidikan Ekonomi Angkatan 2015 Fakultas Ekonomi Universitas Negeri Gorontalo dapat dipengaruhi oleh penggunaan telepon seluler. Sehingga dapat disimpulkan hasil penelitian ini terdapat pengaruh yang signifikan dan positif terhadap penggunaan telepon seluler terhadap hasil belajar mahasiswa pada Program Studi S1 Pendidikan Ekonomi Angakatan 2015 Fakultas Ekonomi Universitas Negeri Gorontalo. Pengaruh positif ini mengindikasikan bahwa apabila penggunaan telepon seluler diterapkan dengan baik, maka hasil belajar mahasiswa pada Program Studi S1 Pendidikan Ekonomi Angakatan 2015 Fakultas Ekonomi Universitas Negeri Gorontalo juga akan semakin meningkat. Hasil penelitian ini sejalan dengan penelitian yang telah dijelaskan pada kajian relevan yang sebelumnya, sebagai perbandingan dari penelitian yang dilakukan pada Program Studi S1 Pendidikan Ekonomi angkatan 2015 Fakultas Ekonomi Universitas Negeri Gorontalo. Dari kelima penelitian relevan sebelumnya yang ada dalam kajian penelitian yang relevan, Hasil penelitian ini diperkuat oleh Ina Astari Utaminingsih (2006) menyebutkan Penggunaan telepon seluler dilakukan pada waktu yang tidak ditentukan. Hal ini menunjukan orang menggunakan telepon seluler sesuai keinginan mereka, tidak ada batas waktu dalam penggunaannya biasa pagi, siang, malam bahkan dini hari. Berdasarkan penjelasan di atas dan hasil ana- 
lisis data maka hipotesis penelitian menyatakan bahwa terdapat "Pengaruh Penggunaan Telepon Seluler Terhadap Hasil Belajar Mahasiswa Pada Program Studi S1 Pendidikan Ekonomi Angakatan 2015 Fakultas Ekonomi Universitas Negeri Gorontalo" dapat diuji kebenaran atau dapat diterima dalam penelitian ini.

\section{Kesimpulan}

Berdasarkan hasil penelitian dapat ditarik kesimpulan bahwa ada pengaruh yang signifikan dalam penggunaan telepon seluler terhadap hasil belajar mahasiswa, sehingga hipotesis yang berbunyi "Terdapat Pengaruh Penggunaan Telepon Seluler Terhadap Hasil Balajar Mahasiswa pada Program Studi S1 Pendidikan Ekonomi Angakatan 2015 Fakultas Ekonomi Universitas Negeri Gorontalo" dapat diterima.

\section{Daftar Pustaka}

Arikunto, S. 2002. Prosedur Penelitian, Suatu Pendekatan Praktek. Jakarta: Rineka Cipta

Dimyati dan Mudjiono. 2009. Belajar dan Pembelajaran. Jakarta: PT Rineka Cipta.

Hamalik, Oemar. 2006. Proses Belajar Mengajar. Jakarta: PT Bumi Aksara

Mulyana. 2012. Pengertian Hasil Belajar \& Faktor Yang Mempengaruhinya. (online)

Nashar, H. 2004. Peranan Motivasi \& Kemampuan Awal. Jakarta: Delia Press

Nur Ibrahim, Rohmat. Terampil Berkomputer Teknologi Informasi dan Komunikasi Untuk Kelas VII SMP/MTs. Jakarta. Pusat Perbukuan Kementerian Pendidikan Nasional
Nune, Surawati. 2016. Pengaruh penggunaan telepon seluler terhadap aktivitas belajar mahasiswa Program Studi Pendidikan Ekonomi Angkatan 2013 Tahun Akademik 2015/2016. (skripsi)

Nurdin, 2005. Sistem komunikasi indonesia, jakarta: Rajawali pers

Prof. Dr. Suharsimi Arikunto. Agustus 2006. PROSEDUR PENELITIAN Suatu Pendekatan Praktik. Jakarta: PT Rineka Cipta

Prof. DR. Sugiyono. Juni 2009. Statistika Untuk Penelitian. Bandung: CV. Alfabeta

Riduwan, Dr. 2013. Belajar Mudah Penelitian Untuk Guru - Karyawan Dan Peneliti Pemula. Penerbit Alfabeta. Bandung.

Sudjana, Nana. 2010. Penilaian Hasil Proses Belajar Mengajar. (Cet.XV). Bandung: PT. Ramaja Rosdakarya.

Sudjana, Nana. 2004. Dasar-dasar proses belajar mengajar. Bandung: Sinar Baru Algensindo Offset.

Sugiyono, 2013. Metode Penelitian Pendidikan. Bandung; ALFABETA

Surakhmad, Winarno. 1980. Interaksi Belajar Mengajar. Bandung: Jemmars

Uswatun, Dampak Positif dan Negatif HP Bagi Pelajar, www.edukasi,kompasiana.com (diakses pada 16 agustus 2017)

www. Dewalangit.com. Fungsi Handfhone Bagi Masyarakat Indonesia. Di akses pada tanggal 28 Agustus 2017.

Wahidmurni, Alifin Mustikawan, dan Ali Ridho. 2010. Evaluasi Pembelajaran: Kompetensi dan Praktik. Yogyakarta: Nuha Letera.

Wiranto. F. A. 2004. Telepon Seluler. Semarang: Pustaka Soegijo Pranata

Jambura : Economic Education Journal,Volume 1, Issue 1 January 2019. 